\title{
Symptoms and Subtypes of Depression Among Adoles- cents Distinguished by the Dexamethasone Suppression Test: A Preliminary Report
}

\author{
Norman E. Alessi and Douglas R. Robbins
}

Received September 30, 1983; revised version received January 17. 1984; accepted January 29. 1984.

\begin{abstract}
Twenty-three adolescents hospitalized on an inpatient psychiatric unit underwent a dexamethasone suppression test (DST) and were diagnosed as having major depressive disorder by interviewers blind to the DST results. These patients were divided into four categories according to whether they had major depressive disorders, endogenous (MDDe) or nonendogenous (MDD), and whether they were nonsuppressors $(+)$ or suppressors $(-)$ in response to the DST, i.e., MDDe (+), MDDe (-), MDD (+), or MDD (-). Psychomotor features significantly differentiated the MDDe group from the MDD group. Among symptoms this further differentiated the MDDe (+) from the MDD (-) group. The primary subtype of depression occurred significantly more frequently among the MDDe group than the MDD group. The primary subtype also occurred more frequently among the MDDe (+) group than the MDD (-) group, whereas the MDD (-) group had a greater frequency of secondary depression.
\end{abstract}

Key Words. Adolescence, depression, dexamethasone suppression test.

The dexamethasone suppression test (DST) has been proposed as a diagnostic test not only in adults (Brown et al., 1979; Carroll et al., 1980a, 1981; Brown and Qualls, 1981; Evans and Nemeroff, 1983), but in adolescents (Crumley et al., 1982; Extein et al., 1982; Robbins et al., 1982 $b$ ) as well. When applied to psychiatrically hospitalized adolescents, the DST has been shown to have a specificity of $85-90 \%$ and a sensitivity of $40-55 \%$. In adults controversy has begun to develop, with challenges to earlier claims of the DST's clinical applicability. Studies with significant numbers of high false positives have been reported, especially in adult patients who have lost weight (Edelstein et al., 1983) or are alcoholic (Swartz and Dunner, 1982). Other studies have focused on its low sensitivity, specificity, and diagnostic confidence in general psychiatric populations (Grosser et al., 1983; Keitner et al., 1983; Kabkin et al., 1983). While the clinical applicability of the DST will continue to be studied, it is indisputably a useful research tool in the study of affective disorders, and it is in this context that the present study was undertaken.

In adults a number of studies have attempted to determine if specific depressive symptomatolngy and subtypes occur with different frequencies among subjects with

\footnotetext{
Norman E. Alessi, M.D., and Douglas R. Robbins, M.D., are Assistant Professors, Department of Psychiatry, University of Michigan. (Reprint requests to Dr. N.E. Alessi, Mental Health Research Institute, 205 Washtenaw Pl., Ann Arbor, MI 48109, USA.)

0165-1781 $84 \$ 03.00 @ 1984$ Elsevier Science Publishers B.V.
} 
major depressive disorders who are nonsuppressors versus suppressors. In contradiction to earlier reports of there being no difference between the symptom presentation of nonsuppressors and suppressors (Schlesser et al., 1980), others have reported differences in cognitive functioning (Brown and Qualls, 1981), paranoid symptoms (Rudorfer et al., 1982; Caroff et al., 1983; Nasr et al., 1983), and sleep disturbances (Reus, 1982; Nasr et al., 1983), with both middle and late insomnia reported most frequently in nonsuppressors. Further, a number of proposals have been made suggesting a subtyping of major depressive disorders, including the presence or absence of suppression as a major consideration. In previous studies, correlations between DST response and familial patterns (Schlesser et al., 1979; Targum et al., 1982), and between DST response and primary depression (Carroll et al., 1980 $b$; Brown and Shuey, 1980; Schatzberg et al., 1983) have been reported. To date the studies of adolescents with major depressive disorder given the DST have focused on issues of specificity and sensitivity within this diagnostic group. The issues of correlation with diagnostic symptoms, subtypes, or genetic subtypes remain to be studied. Given these data, and their possible relationship to treatment (Brown and Qualls, 1981), a number of questions arise: (1) Are there specific symptoms that correlate with nonsuppression among adolescents with major depressive disorders? (2) Are there subtypes (e.g., primary, secondary, psychotic) that are found more frequently among subjects with nonsuppression? (3) Clinically, what can be said for the usefulness of the DST in diagnosing specific subtypes of major depressive disorder? The following is a pilot study undertaken to begin an examination of these issues.

\section{Methods}

All subjects admitted to the Adolescent Unit, University of Michigan are interviewed by two child psychiatrists using the Schedule for Affective Disorders and Schizophrenia (SADS) (Spitzer and Endicott, 1978) and diagnosed using the Research Diagnostic Criteria (RDC) (Spitzer et al., 1977). Diagnostic assessments are made without knowledge of DST results. All subjects had been drug free for 2 weeks at the time of the interview and the administration of the DST. Using this format, our group (Robbins et al., 1982a; Alessi et al., in press) and others (Strober et al., 1981 $a, 1981 b$ ) have demonstrated that major depressive disorders can reliably be diagnosed among adolescents. Concurrently, all subjects received the standard dexamethasone suppression test, which consists of $1 \mathrm{mg}$ of dexamethasone taken by mouth on day 1 at $2330 \mathrm{~h}$. Blood samples are taken for cortisol determination predexamethasone at $2300 \mathrm{~h}$ on day $\mathrm{l}$, and postdexamethasone at $0800 \mathrm{~h}, 1600 \mathrm{~h}$, and $2300 \mathrm{~h}$ on day 2 . Cortisol levels were determined using a standard laboratory technique (Murphy, 1967). Nonsuppressors were defined as subjects whose postdexamethasone cortisol levels exceeded $5 \mu \mathrm{g} / \mathrm{dl}$. Of 45 patients interviewed, 9 refused the DST, and 8 were excluded, according to criteria described elsewhere (Robbins et al., 1983). The 23 adolescents who had the DST and were diagnosed as major depressive disorders are the subjects of this analysis.

Statistical analysis consisted of the Fisher Exact Probability Test, one-way analysis of variance (ANOVA), and Kruskal-Wallis ANOVA where appropriate.

\section{Results}

Subjects. Among the patients with major depressive disorders who received the dexamethasone suppression test (Table I), 15(65\%) of the subjects were endogenously depressed, and $8(35 \%)$ were nonendogenously depressed. Of these subjects, all who 
were nonsuppressors were endogenously depressed. This group represented $40 \%$ of those endogenously depressed, and $26 \%$ of the total population. No subjects were both nonendogenously depressed and nonsuppressors. For the presentation of the results, the following abbreviations will be used: major depressive disorders, endogenous, dexamethasone positive--MDDe (+); major depressive disorders, endogenous, dexamethasone negative-MDDe (-); major depressive disorders, nonendogenous, dexamethasone negative-MDD (-).

Table 1. Demographic data

\begin{tabular}{|c|c|c|c|c|}
\hline & \multirow[b]{2}{*}{ Sex } & \multirow[b]{2}{*}{$n$} & \multicolumn{2}{|c|}{ Age } \\
\hline & & & Mean & SD \\
\hline \multicolumn{5}{|l|}{$\begin{array}{l}\text { Major depressive disorders } \\
\text { endogenous }\end{array}$} \\
\hline $\begin{array}{l}\text { Dexamethasone positive } \\
(n=6)\end{array}$ & $\begin{array}{l}M \\
F\end{array}$ & $\begin{array}{l}3 \\
3\end{array}$ & 17.401 & 0.60 \\
\hline $\begin{array}{l}\text { Dexamethasone negative } \\
\qquad(n=9)\end{array}$ & $\begin{array}{l}M \\
F\end{array}$ & $\begin{array}{l}4 \\
5\end{array}$ & 15.42 & 0.33 \\
\hline \multicolumn{5}{|l|}{$\begin{array}{l}\text { Major depressive disorders } \\
\text { nonendogenous }\end{array}$} \\
\hline $\begin{array}{l}\text { Dexamethasone positive } \\
(n=0)\end{array}$ & - & - & - & - \\
\hline $\begin{array}{l}\text { Dexamethasone negative } \\
(n=8)\end{array}$ & $\begin{array}{l}M \\
F\end{array}$ & $\begin{array}{l}7 \\
1\end{array}$ & 15.63 & 0.90 \\
\hline
\end{tabular}

There were no significant differences in distribution by sex between the three groups. There was a statistically significant difference in the ages among the groups, with the MDDe $(+)$ being significantly older than either of the other two groups (ANOVA, $d f=2, p<0.00079$ ).

Plasma Cortisol Values. Table 2 contains the predexamethasone and postdexamethasone cortisol values for these three groups. By definition both the MDDe(-) and MDD (-) groups showed suppression at all postdexamethasone plasma cortisol determinations. The postdexamethasone cortisol levels for the MDDe (+) group demonstrated a greater degree of deviation from the mean at each time sampling point, indicating considerable variation in the patterns of nonsuppression. A comparison of the cortisol values per time point shows the mean predexamethasone cortisol value $(2300 \mathrm{~h})$ of the MDDe (+) group not to be significantly greater than either that of the MDDe (-) or that of the MDD (-) group (ANOVA, $d f=2, \mathrm{NS}$ ). Due to the violation of the equality of variance, other time points were compared using nonparametric analysis (Kruskal-Wallis). Based on nonparametric analysis, significant differences were found at mean postdexamethasone values of $1600 \mathrm{~h}$ and $2300 \mathrm{~h}(p<0.0320$ and $p$ $<0.0009$, respectively).

Further, to determine whether the baseline cortisols for the subjects from each group, as well as from all groups, varied with age, an analysis of the covariation of age 
with cortisol was made. A significant covariation was not determined at any of the sampling time points. Nonsuppression (values of cortisol greater than $5 \mu \mathrm{g} / \mathrm{dl}$ ) occurs at a number of sampling time points. The frequency of distribution of nonsuppression at each time sampling point of cortisol postdexamethasone is: $0800 \mathrm{~h}-50 \%, 1600 \mathrm{~h}-$ $67 \%$, and $2300 \mathrm{~h}-50 \%$.

Table 2. Mean serum cortisol $(\mu \mathrm{g} / \mathrm{dl})$ in adolescents with major depressive disorders

\begin{tabular}{|c|c|c|c|c|c|}
\hline & & \multicolumn{4}{|c|}{ Mean serum cortisol $(\mu \mathrm{g} / \mathrm{dl})$} \\
\hline & & $2300 \mathrm{~h}$ & 0800h & $1600 \mathrm{~h}$ & $2300 \mathrm{~h}$ \\
\hline \multicolumn{6}{|l|}{$\begin{array}{l}\text { Major depressive disorders } \\
\text { endogenous }\end{array}$} \\
\hline $\begin{array}{l}\text { Dexamethasone positive } \\
(n=6) \\
\text { Dexamethasone negative } \\
(n=9)\end{array}$ & $\begin{array}{l}\text { Mean } \\
\text { SD } \\
\text { Mean } \\
\text { SD }\end{array}$ & $\begin{array}{l}8.64 \\
5.68 \\
4.43 \\
5.31\end{array}$ & $\begin{array}{l}6.07 \\
6.65 \\
1.20 \\
0.77\end{array}$ & $\begin{array}{l}5.101 \\
3.64 \\
1.11 \\
0.40\end{array}$ & $\begin{array}{l}5.942 \\
2.35 \\
0.97 \\
0.34\end{array}$ \\
\hline \multicolumn{6}{|l|}{$\begin{array}{l}\text { Major depressive disorders } \\
\text { nonendogenous }\end{array}$} \\
\hline $\begin{array}{l}\text { Dexamethasone positive } \\
(n=0)\end{array}$ & $\begin{array}{l}\text { Mean } \\
\text { SD }\end{array}$ & - & - & - & - \\
\hline $\begin{array}{l}\text { Dexamethasone negative } \\
(n=8)\end{array}$ & $\begin{array}{l}\text { Mean } \\
\text { SD }\end{array}$ & $\begin{array}{l}2.74 \\
2.00\end{array}$ & $\begin{array}{l}1.84 \\
1.03\end{array}$ & $\begin{array}{l}1.87 \\
1.11\end{array}$ & $\begin{array}{l}1.66 \\
0.86\end{array}$ \\
\hline
\end{tabular}

1. Kruskal-Wallis, $p<0.0320$.

2. Kruskal-Wallis, $p<0.0009$.

Symptoms. Table 3 shows the frequency of occurrence of the RDC symptoms for MDDe and MDD groups. An analysis comparing MDDe with MDD demonstrated that difficulties of psychomotor functioning were found more frequently among subjects who were MDDe (Fisher Exact Probability Test, $p<0.025$ ). The psychomotor functioning of five of the six subjects with MDDe $(+)$ was severe enough to be classified as an RDC subtype, i.e., four had retarded subtypes and one had an agitated subtype. When the MDDe (+) group was further compared to the MDD (-) group, psychomotor disturbances continued to be found more frequently among the MDDe (+) group (Fisher Exact Probability Test, $p<0.01$ ). No further significant differences emerged from an analysis using the Fisher Exact Probability Test to compare symptoms of the following combinations: $\operatorname{MDDe}(+)$ vs. MDDe(-), MDDe(+) vs. MDD(-), and MDDe (-) vs. MDD (-).

RDC Subtypes. When MDDe was compared to the MDD group, the MDDe group was found to have a greater frequency of primary depressive episodes (Table 4). Also, it was found to have a greater frequency of the psychotic subtype. When the MDDe (+) group was further compared to the MDD (-) group, it was only found to be significantly different in the more frequent occurrence of the primary subtype. 
Table 3. RDC depression symptoms

\begin{tabular}{|c|c|c|c|c|c|}
\hline Symptoms & $\begin{array}{c}\text { MDD-END } \\
\text { Dex }+ \\
(n=6)\end{array}$ & $\begin{array}{c}\begin{array}{c}\text { MDD-END } \\
\text { Dex- }\end{array} \\
(n=9)\end{array}$ & $p$ values ${ }^{1}$ & $\begin{array}{l}\text { MDD-Non- } \\
\text { END Dex- } \\
(n=8)\end{array}$ & $p$ values ${ }^{2}$ \\
\hline $\begin{array}{l}\text { Poor appetite, weight loss or } \\
\text { weight gain }\end{array}$ & 5 & 8 & NS & 4 & NS \\
\hline Insomnia or hypersomnia & 6 & 9 & NS & 8 & NS \\
\hline $\begin{array}{l}\text { Psychomotor retardation or } \\
\text { agitation }\end{array}$ & 6 & 7 & 0.01 & 3 & 0.02 \\
\hline Loss of interest & 4 & 8 & NS & 6 & NS \\
\hline Loss of energy & 6 & 8 & NS & 8 & NS \\
\hline Feelings of worthlessness & 5 & 7 & NS & 6 & NS \\
\hline $\begin{array}{l}\text { Diminished ability to think or } \\
\text { concentrate }\end{array}$ & 6 & 8 & NS & 5 & NS \\
\hline $\begin{array}{l}\text { Recurrent thoughts of death or } \\
\text { suicidal attempts }\end{array}$ & 6 & 8 & NS & 6 & NS \\
\hline
\end{tabular}

1. Fisher Exact Probability Test, MDD-END Dex + vs. MDD-END Dex-

2. Fisher Exact Probability Test, MDD-END Dex + vs. MDD-Non-END Dex-

Table 4. RDC depression subtypes

\begin{tabular}{|c|c|c|c|c|c|}
\hline Symptoms & $\begin{array}{l}\text { MDD-END } \\
\text { Dex+ } \\
(n=6)\end{array}$ & $\begin{array}{l}\text { MDD-END } \\
\text { Dex- } \\
(n=9)\end{array}$ & $p$ values 1 & $\begin{array}{l}\text { MDD-Non- } \\
\text { END Dex- } \\
(n=8)\end{array}$ & $p$ values 2 \\
\hline Primary & 6 & 9 & NS & 4 & 0.04 \\
\hline Secondary & 0 & 0 & NS & 3 & NS \\
\hline Recurrent & 3 & 2 & NS & 2 & NS \\
\hline Psychotic & 1 & 5 & NS & 0 & NS \\
\hline Incapacitating & 4 & 9 & NS & 4 & NS \\
\hline Endogenous & 6 & 9 & 0.0001 & 0 & 0.0001 \\
\hline Agitated & 1 & 3 & NS & 2 & NS \\
\hline Retarded & 4 & 6 & NS & 2 & NS \\
\hline Situational & 0 & 1 & NS & 3 & NS \\
\hline Simple & 2 & 4 & NS & 3 & NS \\
\hline
\end{tabular}

1. Fisher Exact Probability Test, MDD-END Dex+ vs. MDD-END Dex-.

2. Fisher Exact Prubabilily Test, MDD-END Dex+ vs. MDD-Nun-END Dex-..

\section{Discussion}

Two factors must be kept in mind when the results of this study are considered: (1) the small sample size and (2) the difference in age between the MDDe $(+)$ group and both the MDDe (-) and MDD (-) groups. As compared to the other studies of hospitalized adolescents, the age of the MDDe (+) group is older (Extein et al., 1983; Friedman et al., 1983; Targum and Capodano, 1983). The degree to which this factor contributes to the findings is unknown. A study (Strober et al., 1981 b) comparing the frequency of 
occurrence of symptoms and subtypes between adolescents and adults with major depressive disorders showed few differences between the adolescent (mean age 15.04 years) and adult groups. In view of this study, age would not appear to explain the difference reported here.

Of importance when considering the cortisol values is the occurrence of late escape in two of the six subjects (33\%). If $1600 \mathrm{~h}$ values were used alone, only four of the six or $67 \%$ of the cases would be detected. Certainly, if nothing else, this indicates the need for multiple plasma sampling after the administration of dexamethasone. A recent study (Goggans et al., 1983) clearly demonstrates the increase in sensitivity from $48 \%$ to $62 \%$ with multiple time point sampling in a clinical population.

The primary depressive subtype was identified in $83 \%$ of the total sample of 23 subjects. All subjects who were MDDe, whether suppressors or nonsuppressors, had primary depressive disorder, whereas only $50 \%$ of the nonendogenous MDD group had primary depressive disorders. In adults, data have demonstrated a strong correlation of DST nonsuppression with primary depressive disorders (Brown and Shuey, 1980; Carroll et al., 1980 b). Our observation lends support to this argument. Of clinical note, the adolescents whom we diagnosed as having primary depressive disorders were seldom diagnosed before hospitalization. More often, they were given labels of "acting out" or having "adjustment disorders." since $31 \%(6 / 19)$ of our subjects with primary depressive disorders demonstrated a biological abnormality, it is apparent that care must be taken in making this diagnostic distinction.

\section{References}

Alessi, N.E., McManus, M., Brickman, A., and Grapentine, W.L. The characterization of affective disorders in serious juvenile offenders. Journal of Affective Disorders (in press).

Brown, W.A.. Johnston, R., and Mayfield, D. The 24 hour dexamethasone suppression test in a clinical setting. American Journal of Psychiatry, 136, 543 (1979).

Brown, W.A., and Qualls, C.B. Pituitary-adrenal-disinhibition in depression: Marker of a subtype with characteristic clinical features and response to treatment? Psychiatry Research, 4, $115(1981)$.

Brown, W.A., and Shuey, I. Response to dexamethasone and subtype of depression. Archives of General Psychiatry, 37, 747 (1980).

Caroff, S., Winokur. A., Rieger, W.. Schweizer, E., and Amsterdam, J. Response to dexamethasone in psychotic depression. Psichiatry Research, 8, 59 (1983).

Carroll, B.J., Feinberg, M., Greden, J.F., Haskett, R.F., James, N.Mcl., Steiner, M., and Tarika, J. Diagnosis of end ogenous depression: Comparison of clinical, research, and neuroendocrine criteria. Journal of Affective Disorders, 2, 177 (1980a).

Carroll, B.J., Feinberg, M., Greden, J.F., Tarika, J., Albala, A.A., Haskett, R.F., James, N.Mcl., Kronfol, Z., Lohr, N., Steiner, M., deVigne, J.P., and Young, E. A specific laboratory test for the diagnosis of melancholia: Standardization, validation, and clinical utility. Archives of General Psychiatry, 38, 15 (1981).

Carroll, B.J., Greden, J.F., Feinberg, M., James, N.Mcl., Haskett, R.F., Steiner, M., and Tarika, I. Neuroendocrine dysfunction in genetic subtype of primary unipolar depression. Psychiatry Research, 2, 251 (1980b).

Crumley, R.F.. Clevenger, J.. Steinfink. D., and Oldham, D. Preliminary report on the dexamethasone suppression test for psychiatrically disturbed adolescents. American Journal of Psychiatry, 139, 1062 (1982).

Edelstein, C.K., Roy-Byrne, P., Fawzy, F.I., and Domfield, L. Effects of weight loss on the dexamethasone suppression test. American Journal of Psychiatry, 140, 338 (1983). 
Evans, D.L., and Nemeroff, C.B. Use of the dexamethasone suppression test using DSM-III criteria on an inpatient psychiatric unit. Biological Psychiatry, 18, 505 (1983).

Extein, I.K.I., Rosenberg, G., Pottash, A.L.C., and Gold, M. I he dexamethasone suppression test in depressed adolescents. American Journal of Psychiatry, 139, 1617 (1982).

Friedman, R.C., Hurt, S.W., Clankin, J.F., Corn, R., and Aronoff, M.S. Symptoms of depression among adolescents and young adults. Journal of Affective Disorders, 5, 37 (1983).

Goggans, F.C., Wilson, W.R., Gold, M.S., and Pottash, A.L.C. Effect of multiple time point sampling on the sensitivity of the dexamethasone suppression test. American Journal of Psychiatry, 140, 909 (1983).

Grosser, B.I., Brainand, J., Byerley, B., Reimherr, F., and Wood, D. Low sensitivity of dexamethasone suppression testing in melancholia. Annual Meeting of the American Psychiatric Association, New Research Poster, New York (1983).

Keitner, G., Haier, R.J., Qualls, C.B., and Brown, W.A. Is the dexamethasone test clinically useful? Annual Meeting of the American Psychiatric Association, New Research Poster, New York (1983).

Murphy, B.P. Some studies of the protein-binding of steroids and their application to the routine micro and ultramicro measurement of various steroids in body fluids by competitive protein-binding radioassays. Journal of Clinical Endocrinology and Metabolism, 27, 973 (1967).

Nasr, S.J., Pandey, G., Altman, E.G., Gibbons, R., Gaviria, F.M., and Davis, J.M. Symptom profile of patients with positive DST: A pilot study. Biological Psychiatry, 18, 571 (1983).

Rabkin, J.G.. Quitkin, F.M., Stewart, J.W.. McGrath. P.J., and Puig-Antich, J. The dexamethasone suppression test with mildly to moderately depressed outpatients. American Journal of Psychiatry, 140, 926 (1983).

Reus, V.I. Pituitary-adrenal disinhibition as the dependent variable in the assessment of behavioral symptoms. Biological Psychiatry, 17, 317 (1982).

Robbins, D.R., Alessi, N.E., Cook, S., Poznanski, E., and Yanchyshyn, G.W. The use of the Research Diagnostic Criteria (RDC) for depression in adolescent psychiatric inpatients. American Academy of Child Psychiatry, 21, 251 (1982a).

Robbins, D.R., Alessi, N.E., Yanchyshyn, G.W., and Colfer, M.V. The dexamethasone suppression test in adolescents: A preliminary report. American Journal of Psychiatry, 139, 942 (1982b).

Robbins, D.R., Alessi, N.E., Yanchyshyn, G.W., and Colfer, M.V. The dexamethasone suppression test in psychiatrically hospitalized adolescents. Journal of the American Academy of Child Psychiatr., 22, 467 (1983).

Rudorfer, M.V., Hwu, H.G., and Clayton, P.J. Dexamethasone suppression test in primary depression: Significance of family history and psychosis. Biological Psychiatry, 17, 41 (1982).

Schatzberg, A.F., Rothschild, A.J., Stahl, J.B., Bond, T.C., Rosenbaum, A.H., Lofgren, S.B., MacLaughlin, R.A., Sullivan, M.A., and Cole, J.O. The dexamethasone suppression test: Identification of subtypes of depression. American Journal of Psychiatry, 140, 88 (1983).

Schlesser, M.A., Winokur, G., and Sherman, B.M. Genetic subtype of unipolar primary depıessive illness distinguished by liypothalamic-pituitary-adrenal axis activity. Lancet, I, 739 (1979).

Schlesser, M.A., Winokur, G., and Sherman, B.M. Hypothalamic-pituitary-adrenal axis activity in depressive illness. Archives of General Psychiatry, 37, 737 (1980)

Spitzer, R.L., and Endicott, J. The Schedule for Affective Disorders and Schizophrenia. New York State Psychiatric Institute, New York (1978).

Spitzer, R.L., Endicott, J., and Robins, E. Research Diagnostic Criteria (RDC) for a Selected Group of Functional Disorders. 3rd ed. New York State Psychiatric Institute, New York (1977).

Strober. M.. Green, J., and Carlson, G. The reliability of psychiatric diagnosis in hospitalized adolescents. Archives of General Psychiatry, 38, 141 (1981a).

Strober, M., Green, J., and Carlson, G. Phenomenology and subtypes of major depressive disorders in adolescents. Journal of Affective Disorders, 3, 281 (1981b). 
Swartz, C., and Dunner, F.J. Dexamethasone suppression test of alcoholism. Archives of General Psychiatry, 39, 1309 (1982).

largum, S.D., Byrnes, S.M., and Sullivan, A.C. Subtypes of unipolar depression distinguished by the dexamethasone suppression test. Journal of Affective Disorders, 4, 2 I (1982).

Targum, S.D., and Capodano, A.E. The dexamethasone suppression test in adolescent psychiatric inpatients. American Journal of Psychiatry, 140, 589 (1983). 